\title{
Retinomotor movements in the Antarctic fish Trematomus newnesi Boulenger submitted to different environmental light conditions
}

\author{
Lucélia Donatti \& Edith Fanta
}

Departamento de Biologia Celular, Universidade Federal do Paraná. Caixa Postal 19031, 81531-970 Curitiba, Paraná, Brasil. E-mail: donatti@ufpr.br

\begin{abstract}
The Antarctic fish Trematomus newnesi (Boulenger, 1902) occurs from benthic to pelagic habitats, in seasonally and daily varied photic conditions that induce retinomotor movements. Fish were experimentally kept under constant darkness or light, and 12Light/12Dark for seven days. The retinomotor movement of the pigment epithelium was established through the pigment index, while that of the cones was calculated as the length of the myoid. The retinomotor movement of the pigment epithelium in $T$. newnesi, revealed that the adaptation to constant light occurred in the one hour of exposure, remaining constant for the next seven days. However, the adaptation to constant darkness, was slower. The difference between the mean values of the pigment indices in the time intervals of sampling was significant in the first hours of the experiment, and only after six hours they were not significant any more. The myoid of cones became elongated in darkness and contracted in light. In the experiments where $T$. newnesi was exposed initially to 12 hours light followed by 12 hours darkness 12 was evidenced that the speed and intensity of the retinomotor movements was higher when darkness changed into light, than when light changed into darkness.

KEY WORDS. Photic variation; photoreceptors; retina.
\end{abstract}

RESUMO. Movimento retinomotor do peixe antártico Trematomus newnesi Boulenger submetido a diferentes condições fóticas. O peixe antártico Trematoms newnesi (Boulenger, 1902) vive em habitats benticos à pelágicos, em condições fóticas que variam sazonalmente e diariamente, induzindo os movimentos retinomotores. Peixes foram mantidos experimentalmente, durante sete dias, sob luz ou escuro constante, e 12 horas luz/12 horas escuro. $O$ movimento retinomotor do epitélio pigmentar foi estabelecido através do índice de pigmento enquanto que o dos cones foi calculado através do comprimento do mióide. O movimento retinomotor do epitélio pigmentar de $T$. newnesi revelou que a adaptação à luz constante ocorreu na primeira hora de exposição, permanecendo constante para os próximos sete dias. No entanto, a adaptação para o escuro constante foi mais lenta. A diferença entre a média dos valores dos índices de pigmento nos intervalos de tempo foi significativa nas primeiras quatro horas de exposição ao escuro e somente seis horas após não houve mais diferença significativa entre os tempos. O mióide dos cones alonga-se no escuro e contrai-se no claro. Nos experimentos onde $T$. newnesi foi submetido a 12 horas luz seguido por 12 horas escuro foi evidenciado que a velocidade e a intensidade dos movimentos retinomotores foi maior quando o animal passa do escuro para a luz do que quando passa da luz para o escuro.

PALAVRAS-CHAVE. Fotorreceptores; retina; variação fótica.

In lower vertebrates, photoreceptors and pigment epithelium perform retinomotor or photomechanical movements (Müller 1856, Walls 1942, Ali 1975, EAstMAnN 1988, MacDonald \& Montgomery 1991, Burnside 2001), in response to the changes in environmental luminosity, to optimise vision in all light conditions (BuRNSIDE \& NAGLE 1983, NiCOL 1989). In continuous darkness, the retinomotor movements are usually cyclic and persistent, corresponding to the hours of dusk and dawn. These endogenous movements (ALI 1975) were observed in many fishes, with the exception of Salmonidae (ENGSTRöm \& Rosstorp
1963, John et al. 1967, Olla \& Marchioni 1968). In some Antarctic fish the retinomotor movements were studied for many authors (Meyer-Rochow \& Klyne 1982, Pankhurst \& Montgomery 1989, Phan \& Nachi 1990, MacDonald \& Montgomery 1991). EASTMAN (1988) suggested that the retinomotor movement in Antarctic Nototheniidae at McMurdo could be less important than for fish in temperate regions.

Trematomus newnesi (Nototheniidae, Perciformes) can be benthic (ZADRóZNY 1996), semipelagic (RICHARDSON 1975, DANIELS 1982, VACCHI \& LAMESA 1995), cryopelagic (ANDRIASHEV 1970), 
and do vertical migrations (DeWitT 1971, Fischer \& HurEau 1985), occurring also in shallow waters, among algae, as in Admiralty Bay, where they were collected. Therefore, one expects that they should have some retinomotor movements as adaptation to so many different photic conditions in their habitats, and to face the Antarctic seasonally extreme photoperiods.

The present research aimed to describe the temporal sequence of retinomotor movements of the Antarctic fish Trematomus newnesi, exposed experimentally to continuous light, continuous darkness, and alternate light and darkness, and to verify if these movements persist in constant light or darkness.

\section{MATERIAL AND METHODS}

Trematomus newnesi Boulenger, 1902 were collected by trawl net, at a depth of $15 \mathrm{~m}$, in Admiralty Bay $\left(62^{\circ} 09^{\prime} \mathrm{S}\right.$, $\left.58^{\circ} 26^{\prime} \mathrm{W}\right)$, King George Island, South Shetlands, and the experiments were carried out at the Brazilian Antarctic Station Comte. Ferraz. Initially, T. newnesi $(\mathrm{n}=54)$ of mean total length $8.3 \pm 2.0 \mathrm{~cm}$ (mean + S.D.) were acclimated to the laboratory, in $80 \mathrm{~L}$ aquaria, for seven days, in a photoperiod of 20 hours light and four hours dark (20L/4D), the same as in the natural environment at the moment of collection. The temperature was maintained at $1 \pm 0.5^{\circ} \mathrm{C}$ (mean + S.D.), the salinity was kept at $34 \pm 0.5$ ppt (mean + S.D.), and all fish fed ad libitum.

After acclimation, the fish were distributed in test aquaria, being different photoperiods the only variable: some fish were maintained in continuous light $(24 \mathrm{~L})$, others in constant darkness (24D), and a third group in alternate light and darkness (12L/12D).

All aquaria were isolated from the surrounding environment by green sheets and covered with translucent acrylic, with a daylight lamp above them. When the fish were kept under a light period, the aquaria were covered with grey translucent plaques, which reduced the light intensity at the bottom to 710 lux. To simulate darkness, the aquaria were covered with dark red sheets, reducing the daylight to red. This is a long wavelength light, and the illumination was reduced to one lux at the bottom of the aquaria. The individuals used owned total length of $8.3 \pm 2.5 \mathrm{~cm}$ (mean \pm S.D.). Two repetitions were done for each experiment: 1) After $T_{0}$ the fish $(n=18)$ were exposed to constant darkness for seven days, sacrificed $1\left(\mathrm{~T}_{1}\right)$, $2\left(\mathrm{~T}_{2}\right), 6\left(\mathrm{~T}_{6}\right), 12\left(\mathrm{~T}_{12}\right), 18\left(\mathrm{~T}_{18}\right), 24\left(\mathrm{~T}_{24}\right)$ and $167\left(\mathrm{~T}_{167}\right)$ hours after $\mathrm{T}_{0}$, and the retinas extracted and processed under low intensity red light. 2) After $T_{0}$ the fish $(n=18)$ were exposed to constant light for seven days, sacrificed, and the retinas extracted at the same experimental times as in 1 , and processed under daylight. 3) After $T_{0}$ the fish $(n=28)$ were exposed initially to 12 hours light followed by 12 hours darkness. Between both periods there was the transition time $\left(T_{t}\right)$ when light turned into darkness. The retina was sampled 30 minutes $\left(\mathrm{T}_{30 \mathrm{~min}}\right), 1\left(\mathrm{~T}_{1}\right)$, $2\left(\mathrm{~T}_{2}\right), 4\left(\mathrm{~T}_{4}\right), 8\left(\mathrm{~T}_{8}\right)$ and $12\left(\mathrm{~T}_{12}\right)$ hours after $\mathrm{T}_{0}$, in light and in the same hours in darkness after the $\mathrm{T}_{\mathrm{t}}$. Processing was, respectively, in light and in darkness, as mentioned for 1 and 2.
The retinas were fixed in Bouin's fluid (Culung et al. 1985) for eight hours, and routine processed for optical microscopy, embedded in Paraplast plus ( ${ }^{\circledR}$ Sigma) and stained with Haematoxylin and Eosin (H.E.), for analysis. The length of cones, and expansion of pigments in the epithelium cells was obtained from micrographs. The retinomotor movement of the pigment epithelium cells was determined by the pigment index (Ali 1975). It represents the distance between the Bruch's membrane $(\mathrm{BM})$ and the most apical melanin grain, divided by the distance between the BM and the external limiting membrane (ELM) (Fig. 1). Three measures for each analyzed retina had been made. The distance between the ELM and the basis of the internal segment of double cones (IS) was measured to express the elongation and contraction of the myoid of the internal segment of cones (Fig. 2). Ten cones in each analyzed retina had been measured.

All results were treated statistically by ANOVA test, t-Test, and Tuckey test (Zar 1984). Differences were considered significant when $\mathrm{p} \leq 0.05$. The analysis was done by means of the software Statistic version 5.1 for windows (Statsoft Inc. 1996).

\section{RESULTS}

\section{Retinomotor movement in the pigment epithelium}

In darkness melanin grains were aggregated at the basal region of the epithelial cells, therefore exposing the external segments of the photoreceptors. In light, the movement was in the opposite direction and the melanin grains were concentrated inside the apical projections of the epithelial cells, surrounding the apical portion of the photoreceptors.

The pigment indices for fish exposed continuously to darkness is summarized in figure 3. The differences between the mean values of the pigment indices in the time intervals of collection were significant $\left(\mathrm{F}_{7.40}=3.57 ; \mathrm{p}=0.0044\right)$. At $\mathrm{T}_{2}$ the index was significantly higher than at $\mathrm{T}_{0}(\mathrm{p}=0.0258)$, being the smallest pigment index observed at $\mathrm{T}_{12}$, significantly lower than at $\mathrm{T}_{2}(\mathrm{p}=0.0101)$.

The pigment indices for fish exposed continuously to light is presented in figure 4 . The differences between the mean values of the pigment indices in the interval of times after $\mathrm{T}_{0}$ were significant $\left(\mathrm{F}_{7.40}=5.09 ; \mathrm{p}=0.0003\right)$. The mean value of the pigment index at $\mathrm{T}_{0}$ was significantly lower when compared to the values of all other times $\left(\mathrm{T}_{1}, \mathrm{p}=0.0472 ; \mathrm{T}_{2}, \mathrm{p}=\right.$ $0.0302 ; \mathrm{T}_{6}, \mathrm{p}=0.0043 ; \mathrm{T}_{12}, \mathrm{p}=0.0003 ; \mathrm{T}_{18}, \mathrm{p}=0.0043 ; \mathrm{T}_{167}, \mathrm{p}=$ $0.0061)$, which showed no significant difference among them. The highest mean value was at $\mathrm{T}_{12}$ and the lowest at $\mathrm{T}_{0}$.

When the pigment indices of fish kept in constant light was compared with the indices of those maintained in constant darkness, a significant difference in the sampling intervals $\left(\mathrm{F}_{7.88}=2.23 ; \mathrm{p}=0.0388\right)$ was noticed. There was also a significant difference when both $\mathrm{T}_{1}$ were compared $\left(\mathrm{t}_{1.5}=5.29\right.$, $\mathrm{p}=0.0032)$, as well as the $\mathrm{T}_{6}\left(\mathrm{t}_{1.5}=5.09 ; \mathrm{p}=0.0037\right)$, the $\mathrm{T}_{12}\left(\mathrm{t}_{1.5}\right.$ $=11.11 ; \mathrm{P}=0.0001)$, the $\mathrm{T}_{24}\left(\mathrm{t}_{1.5}=5.74 ; \mathrm{p}=0.0022\right)$, and the $\mathrm{T}_{167}\left(\mathrm{t}_{1.5}=3.34 ; \mathrm{p}=0.0204\right)$. 


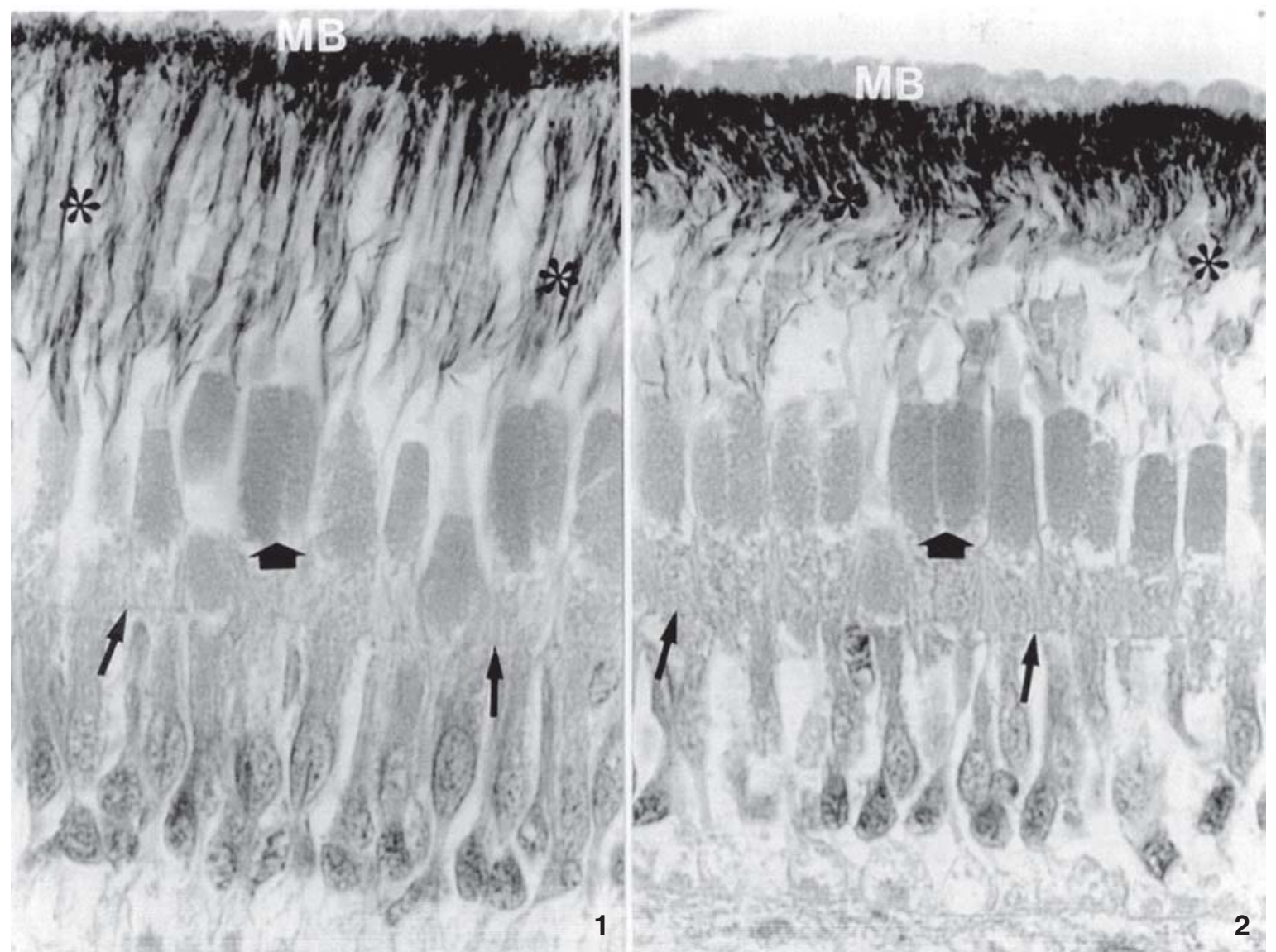

Figures 1-2. Retina of Trematomus newnesi: (1) pigment index - distance between the Bruch's membrane(MB) and the most apical melanin grain (asterisk), divided by the distance between the MB and the external limiting membrane (thin arrow); and (2) length of cones distance between the external limiting membrane (thin arrow) and the basis of the internal segment of double cones (thick arrow).

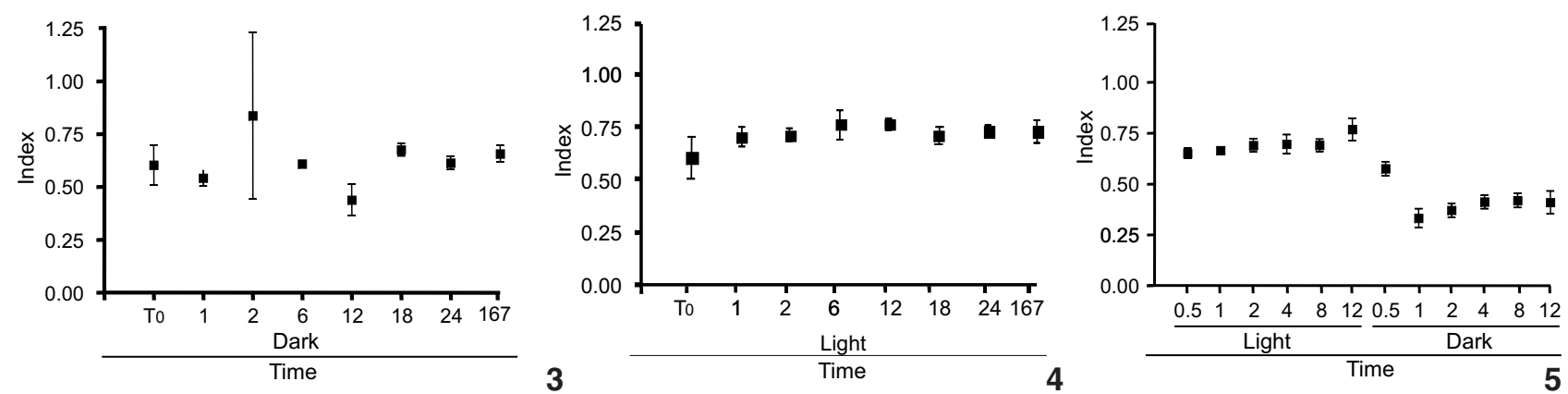

Figures 3-5. Mean \pm SD pigment indices (index) of the retina of Trematomus newnesi exposed continuously to darkness (3) and to light, after $\mathrm{T}_{0}$ (initial time), and to a photoperiod of 12 hours light followed by 12 hours darkness (5). Time in hours and index ( $\mu \mathrm{m}$ ).

The pigment indices for fish kept in photoperiod 12L/ $12 \mathrm{D}$ are compiled in figure 5 . The differences between the mean values of the pigment indices in the time intervals were significant $\left(\mathrm{F}_{11.60}=95.49 ; \mathrm{p}=0.0000\right)$. Along the first eight hours after $\mathrm{T}_{0}$, in light, the differences between the mean values were not significant, but at $T_{12}$ the mean value was significantly higher when compared with all other times, with the exception of $\mathrm{T}_{4}\left(\mathrm{~T}_{30 \mathrm{~min}}, \mathrm{p}=0.0002 ; \mathrm{T}_{1}, \mathrm{p}=0.0012 ; \mathrm{T}_{2}, \mathrm{p}=0.0412 ; \mathrm{T}_{8^{\prime}}\right.$

Revista Brasileira de Zoologia 24 (2): 457-462, junho 2007 
$p=0.0429$ ). After $T_{t}$, in darkness, the differences between the mean values were not significant at $\mathrm{T}_{4}, \mathrm{~T}_{8}$, and $\mathrm{T}_{12}$. All differences between the mean values in the intervals of sampling in light were significantly higher when compared with the mean values in darkness ( $p$ between 0.0475 and 0.0001 ), with the exception of 30 minutes light and 30 minutes darkness.

\section{Retinomotor movements of cones}

The distance between ELM-IS in the double cones, at different times after $T_{0}$, when fish were kept constantly in darkness, are in Fig. 6 . The differences between the mean values in the sampling intervals were significant $\left(\mathrm{F}_{7.152}=25.66, \mathrm{p}=0.0000\right)$. The highest mean values were obtained at $\mathrm{T}_{24}$, and $\mathrm{T}_{167}$, and the lowest at $\mathrm{T}_{0}$. From the first to the sixth hour in the dark the differences in ELM-IS mean values were not significant. From $\mathrm{T}_{12}$ to $\mathrm{T}_{18}$ the value was constant but significantly lower than at the other exposure times ( $\mathrm{p}$ between 0.0428 and 0.0000).

The cones' myoid movement at different times after $\mathrm{T}_{0}$, when fish were kept constantly in light, are in figure 7 . The differences between the mean values at different times after $\mathrm{T}_{0}$ were significant $\left(\mathrm{F}_{7152}=4.12 ; \mathrm{p}=0.0003\right)$. At $\mathrm{T}_{0}$ and $\mathrm{T}_{1}$ the ELMIS was significantly lower than at $\mathrm{T}_{12}(\mathrm{p}=0.0060$ and 0.0042 respectively) and $\mathrm{T}_{18}(\mathrm{p}=0.0419$ and 0.0315 respectively). The highest value was obtained at $\mathrm{T}_{12}$ and the lowest at $\mathrm{T}_{0}$.

When the ELM-IS distance in fish kept in constant light was compared with the distance in those maintained in constant darkness, a significant difference in the mean values was obtained $\left(\mathrm{F}_{7.312}=6.53 ; \mathrm{p}=0.0000\right)$. If the times after $\mathrm{T}_{0}$ of fish kept in constant light were compared with those kept in constant darkness, significant differences were obtained at $\mathrm{T}_{1}\left(\mathrm{t}_{1.19}=10.33 ; \mathrm{p}=\right.$ $0.0000), \mathrm{T}_{2}\left(\mathrm{t}_{1.19}=3.10 ; \mathrm{p}=0.0058\right), \mathrm{T}_{6}\left(\mathrm{t}_{1.19}=6.88 ; \mathrm{p}=0.0000\right)$, $\mathrm{T}_{24}\left(\mathrm{t}_{1.19}=5.25 ; \mathrm{p}=0.0000\right)$, and $\mathrm{T}_{167}\left(\mathrm{t}_{1.19}=7.61 ; \mathrm{p}=0.0000\right)$.

The mean values of the cones' myoid length in fish maintained in a photoperiod $12 \mathrm{~L} / 12 \mathrm{D}$ are in figure 8 . The differences between the mean values in the sampling intervals were significant $\left(\mathrm{F}_{11.228}=10.46 ; \mathrm{p}=0.0000\right)$. The differences among the mean values during the 12 hours of light were not significant, with the exception of the lowest value, at $\mathrm{T}_{12}(\mathrm{p}=0.0161)$. The lowest value for the distance ELM-IS, was obtained two hours in darkness after $\mathrm{T}_{0}$. It was significantly distinct from all other values in light or in darkness ( $\mathrm{p}$ between 0.0383 and 0.0000). The differences between the mean values in cones sampled during the light hours and during the dark hours were significant at $\mathrm{T}_{30 \min }$ and $\mathrm{T}_{2}$ ( $\mathrm{p}$ between 0.0083 and 0.0000 ).

\section{DISCUSSION}

Luminosity and photoperiod vary seasonally in Polar Regions, being the light reduced to almost darkness during the winter while its presence is practically constant in summer. At the same time, there are variable local weather conditions that affect the amount and the quality of incident light, mainly in shallow regions. The idea to submit T. newnesi to experiments under controlled environmental conditions was to follow the retinomotor movements of the pigment epithelium and of cones along the adaptation process to constant light or constant darkness, or to changes between light and darkness in shorter periods of time. Morphometry allowed a numerical expression of this phenomenon.

The retinomotor movement of the pigment epithelium in T. newnesi, revealed that the adaptation to constant light, by expansion of melanin grains, occurred in the first hour of exposure, remaining constant for the next seven days, when the differences between the mean values were not significant. However, the adaptation to constant darkness, by aggregation of melanin, was slower: the difference between the mean values of the pigment indices in the time intervals of sampling was significant in the first hours of the experiment, and only after six hours they were not significant any more.

The same was observed in fish exposed alternately to 12 hours of light, followed by 12 hours darkness: adaptation to light occurred promptly, in the first hour, and there was no difference between the mean values of the pigment indices till the $12^{\text {th }}$ hour, when it raised slightly. After that, the environment changed to dark, and the adaptation to this condition took place after four hours, being stabilized afterwards.

Based on the histological aspect of the retina MACDONALD \& Montgomery (1991) suggested that the adaptation of some Antarctic fish to darkness occurs along the first four hours of exposure, by a retraction of the pigment epithelium and exposure of the external segments of rods, while during the adaptation to light the external segments were covered after one hour of exposure to light, but this was not proven through a statistical evaluation of the pigment indices.

In the experiments with T. newnesi it was evidenced that the speed and intensity of the retinomotor movements was higher when darkness changed into light, than when light changed into darkness. This can be important in the shallow waters where they occur, such as in Admiralty Bay, when the weather changes, to avoid sudden exposure of the photoreceptors' external segments to light, with bleaching of photopigments and consequent blindness (Ali 1971, 1975, Douglas 1982, KIRSCH et al. 1989).

In T. newnesi exposed continuously to darkness, the elongation of cones occurred in the first hour of exposition to darkness, and along the next 6 hours there was no significant difference between the myoid lengths. From 12 to 18 hours of exposure to darkness the cones contracted, followed by another expansion. When fish were exposed to constant darkness, a contraction of cones was observed 12 hours after $\mathrm{T}_{0}$, and 12 hours later, the cones were elongated. When the fish were kept in constant light, the opposite was observed.

In constant darkness, a cyclic contraction and expansion was observed for many species, with the exception of salmonids (ENGSTRÖm \& Rosstorp 1963, John et al. 1967, Burnside et al. 1983, 1993, BRECKLER \& BURNSIDE 1994), but the amplitude of the movement and the duration of the rhythm seems to vary with the species.

Revista Brasileira de Zoologia 24 (2): 457-462, junho 2007 

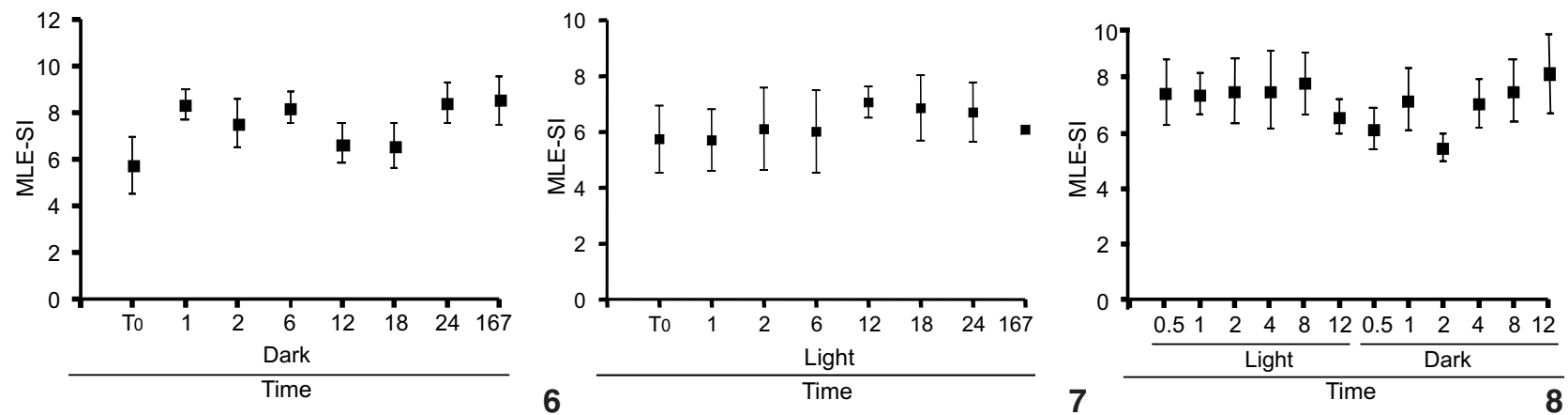

Figures 6-8. Mean \pm SD myoid length of the twin cones (MLE-SI) in the retina of Trematomus newnesi exposed continuously to darkness (6) and to light (7), after $\mathrm{T}_{0}$ (initial time), and to a photoperiod of 12 hours light followed by 12 hours darkness (8). Time in hours and MLE-SI ( $\mu \mathrm{m}$ ).

When T. newnesi that were maintained in a photoperiod of $12 \mathrm{~L} / 12 \mathrm{D}$ came into darkness, the cones started to elongate, reaching their maximal amplitude after 12 hours. However, in constant darkness, cones can reach their maximal extension, while in animals submitted to an alternation of light and dark, the amplitude of cones elongation during the dark phase is smaller, a phenomenon also observed by LEVINSON \& BURNSIDE (1981) for some other species.

Trematomus newnesi occupies various habitats, such as the benthos, the water column beneath ice, or free from ice, and the surface in conjunction with algae banks. They can also perform vertical migration (DeWITt 1971, Fischer \& Hureau 1985). These varied habitats show diverse photic conditions, and vertical migration makes the fish change from dark to illuminated regions or vice versa in short periods of time. Thus, the capability of short-term photomechanical movements in the retina enable these fish to an optimal vision for food search, detection of predators, and places to hide, in all these light conditions.

\section{ACKNOWLEDGEMENTS}

The authors wish to thank the Conselho Nacional de Pesquisa e Desenvolvimento (CNPq) for financial support to the Projects nrs. 480708/96-7, 480844/97-6, and 490103/99-5, and a Productivity in Research stipend for E. Fanta nr.300831/ 93-5; CAPES for a PICDT-Doctorate Stipend to L. Donatti; the SECIRM of the Brazilian Navy, and the staff of the Brazilian Antarctic Station Comandante Ferraz for all logistical support.

\section{REFERENCES}

Ali, M.A.1971. Les responses retinomotrices: caracteres et mechanismes. Vision Research 11: 1225-1228.

AlI, M.A.1975. Retinomotor responses, p. 315-355. In: M.A. AlI (Ed.). Vision in fishes. New York, Plenum, 836p.

Andriashev, A.P. 1970. Cryopelagic fishes of the Arctic and Antarctic and their significance in the polar ecosystems, $p$. 287-304. In: M.V. Holdgate (Ed.) Antarctic ecology. New York, Academic Press, I+604p.
Breckler, J. \& B. Burnside. 1994. Myosin-I in retinal pigment epithelial cells. Investigative Ophthalmology and Visual Science 35: 2489-2499.

BuRnSIDE, B. 2001. Light and circadian regulation of retinomotor movement. Progress in Brain Research 131: 477-485.

Burnside, B. \& B. Nagle. 1983. Retinomotor movements of photoreceptors and retinal pigment epithelium: mechanisms and regulation, p. 67-109. In: N.N. Osborne \& G.J. Chader (Eds). Progress in retinal research. Oxford, Pergamon Press, $337 \mathrm{p}$.

Burnside, B.; E. Wang; K. Pagh-roel \& H. Rey. 1993. Retinomotor movements in isolated teleost retinal cone inner-outer segment preparations (CIS-COS): Effects of light, dark and dopamine. Experimental Eye Research 57: 709-722.

Culling, C.F.A.; R.T. Allison \& W.T. Barr. 1985. Cellular pathology technique. London, Butterworth, 642p.

DANIELS, R.A. 1982. Feeding ecology of some fishes of the Antarctic Peninsula. Fisheries Bulletin 80: 575-588.

DeWiтt, H.H. 1971. Coastal and deepwater benthic fishes of the Antarctic, p.1-10. In: V.C. Bushnell (Ed.) Antarctic Map, Folio Series. New York, American Geographic Society Folio.

Douglas, R.H. 1982. The function of photomechanical movement in the retina of the rainbow trout (Salmo gairdneri). Journal Experimental Biology 96: 389-403.

EASTMAn, J.T. 1988. Ocular morphology in Antarctic notothenioid fishes. Journal Morphology 196: 283-306.

EnGSTRÖM, K. \& E. Rosstorp. 1963. Photomechanical responses in different cone types of Leuciscus rutilus. Acta Zoological et Pathological Antverpiensia 19: 145-166.

Fischer, W. \& J.C. HuREAU. 1985. FAO Species Identification Sheets for fishery purposes: Southernn Ocean. V.II. Rome, Food and Agriculture Organization of United Nations, 471p.

John, K.R.; M. Segall \& L. ZaWaTzKy. 1967. Retinomotor rhythms in the goldfish Carassius auratus. Biological Bulletin 132: 200-210.

KIRSCH, M.; H.J. Wagner \& R.H. Douglas. 1989. Rods trigger light adaptive retinomotor movements in all spectral cone types of a teleost fish. Vision Research 29: 389-396.

Revista Brasileira de Zoologia 24 (2): 457-462, junho 2007 
Levinson, G. \& B. Burnside. 1981. Circadian rhythms in teleost retiniomotor movements - A comparison of the effects of circadian rhythm and light condition on cone length. Investigative Ophthalmology and Visual Science 20: 294 303.

Macdonald, J.A. \& J.C.Montgomery. 1991. The sensory biology of notothenioid fish, p. 145-162. In: G. Di Prisco; B. MARESCA \& B. Tота (Eds). Biology Antarctic fish. Berlin, Springer Verlag, 292p.

Meyer-Rochow, V.B. \& M.A.KLyne. 1982. Retinal organisation of the eyes of three nototheniid fishes from the Ross Sea (Antarctica). Gegenbaurs Morphologisdes Jahrbuch 128: 762 777.

MüLlER, H. 1856. Anatomisch-physiologische Untersuchungen über die Retina bei Menschen und Wirbeltieren. Zeitschrift fuer Wissenschftliche Zoologie 8: 1-122.

Nicol, J.A.C. 1989. The eyes of fishes. Oxford, Claredon Pres, $308 p$.

Olla, L. \& W. Marchioni. 1968. Rhythmic movements of cones in the retina of bluefish Pomatomus saltatrix held in constant darkness. Biological Bulletin 135: 530-536.

Pankhurst, N.W. \& J.C. Montgomery. 1989. Visual function in four Antarctic nototheniid fish. Journal Experimental Biology 142: 211-324.

Phan, M.T. \& A.M. Nachi. 1990. Antarctic fish retina. Histological variations under continuous darkness. Pesquisa Antártica Brasileira 2: 7-11.

RichaRdSON, M.G. 1975. The dietary composition of some Antarctic fish. British Antarctic Survey Bulletin 41: 113-120.

Vacchi, M. \& M. LaMesa. 1995. The diet of the Antarctic fish Trematomus newnesi Boulenger 1902 (Nototheniidae) in Terra Nova Bay, Ross Sea. Antarctic Science 7: 37-38.

WaLLS, G.L. 1942. The vertebrate eye. New York, Hafner, 785p.

ZADróZNY, T. 1996. Fishes of Admiralty Bay caught in 1994 and 1995 (King George Island, South Shetland Islands, Antarctica). Polskie Archiwum Hydrobiologii 43: 347-354.

ZAR, J.H. 1984. Biostatistical analysis. London, Prentice Hall, 929p.

Received in 01.XII.2006; accepted in 01.VI.2007.

Revista Brasileira de Zoologia 24 (2): 457-462, junho 2007 